\title{
DINAMIKA KESEJAHTERAAN PENDUDUK DI BANJARNEGARA
}

\section{Wiwik Puji Mulyani}

Fakultas Geografi, Universitas Gadjah Mada, Yogyakarta, Indonesia wpuji@ugm.ac.id

Diterima : Agustus 2015; Direvisi :Januari 2015; Dipubikasikan:Maret 2016

\begin{abstract}
ABSTRAK Banjarnegara mendapat terdiri dari 20 kecamatan yang telah menetapkan kesejahteraan penduduk menjadi prioritas dalam program pembangungan. Hal ini termaktub dalam Rencana Pembangunan Jangka Panjang Menengah (RPJM) daerah tahun 2011-2016. Berdasarkan hal tersebut, aspek penduduk perlu diketahui serta dianalisis supaya dapat diketahui sejauh mana kesejahteraan masyarakat tersebut ditengah keadaan lingkungan fisik yang demikian. Kesejahteraan dianggap penting karena perubahan tingkatnya dapat menggambarkan sejauh mana tingkat pencapaian sesuatu pembangunan. Tujuan utama penelitian ini adalah untuk mengkaji: 1. Mengkaji dinamika kesejahteraan penduduk Banjarnegara. 2. Mengkaji perbedaan kesejahteraan menurut wilayah di Banjarnegara. Hasil kajian menunjukkan tidak selalu yang mempunyai ciri kekotaan selalu menempati posisi tertinggi. Contohnya adalah Kecamatan Banjarnegara yang merupakan ibukota Kabupaten lebih rendah posisinya dibandingkan Kecamatan Klampok. Kecamatan yang merupakan "transisi” yang maksudnya adalah daerah yang didominasi pertanian namun telah berkembang pula sektor perdagangan dan jasa menduduki peringkat terbaik dalam hal kesejahteraan. Selain Klampok, diketahui bahwa Kecamatan, Kecamatan Punggelan, Kecamatan Mandiraja, Kecamatan Kalibening, Kecamatan Madukara, Kecamatan Pagedongan dan Karangkobar. Kesejahteraan sedang: Bawang, Purwanegara, Banjarmangu, Susuk Wanadadi. Kesejahteraan kurang baik dibandingkan kecamatan yang lain adalah di Pandanarum, Pagentan, Pajawaran, Rakit, Kalibening. Kecamatan ini didominasi aktivitas pertanian dengan beberapa aspek terlihat relatif lebih rendah keadaannya dibandingkan daerah lain. Misalnya keadaan perumahan, pendidikan selain faktor ekonomi.
\end{abstract}

Kata kunci: Banjarnegara; indikator kesejahteraan; kekotaan; kesejahteraan penduduk.

ABSTRACT Banjarnegara consists of 20 districts that have established well-being of the population a priority in development programs. It is stated in Rencana Pembangunan Jangka Panjang Menengah (RPJM) daerah 2011-2016. Based on that vision, should be known and analyzed population aspects and its development over time, to consider the programs related to population. At least it can be seen how far the public welfare amid such circumstances the physical environment. The main objective of this study was to assess: 1. assessing the dynamics of population welfare Banjarnegara. 2. Assessing the welfare differences by region in Banjarnegara. The results show that not always the urbanity characteristic always occupies the highest welfare position. An example is the District Banjarnegara which is the capital district is lower than the District Klampok. District that is "transition" which means that the agriculture-dominated areas, but has also developed trade and services sector ranked the best in terms of well-being. These districts are Klampok, District Punggelan, District Mandiraja, District Kalibening, District Madukara, District Pagedongan and Karangkobar. Districts have medium well being are Purwanegara, Banjarmangu, Wanadadi. Districts with the lowest well being than the other districts are in Pandanarum, Pagentan, Pajawaran, rafts, Kalibening. These districts are dominated agricultural activity with some aspects of the situation looks relatively lower compared to other regions. For example the state of housing, education, economic, conditions.

Key words: Banjarnegara; welfare indicators; urbanity; welfare of the population.

\section{PENDAHULUAN}

Pembangunan diartikan sebagai proses perubahan yang dilakukan manusia untuk membina sebuah peradaban atau memantapkan peradaban tersebut. Pembangunan tidak pernah berhenti dilakukan sejak awal mula dilaksanakan karena pembangunan merupakan suatu proses (Munck, 2013; Todaro, 1991; Lukman et al., 2002). Selain itu pembangunan juga merupakan satu proses multi-dimensi yang meliputi aspek ekonomi, sosial, fisik, moral dan kebudayaan yang berjalan secara terus-menerus dan bergerak dalam beberapa arah pada suatu jangka masa tertentu (Frank, 1978).
Lukman et al. (2002), kesejahteraan merupakan di antara komponen pembangunan menunjukkan bahwa kesejahteraan merupakan hal penting dalam pembangunan. Apalah artinya pembangunan jika hasil yang didapati tidak sesuai dengan keperluan penduduk. Satu negara atau satu kawasan dapat dinyatakan berhasil membangun jika kesejahteraan penduduknya tinggi. Bahkan Abdul et al. (2002) menyatakan bahwa kemajuan sesebuah negara diukur berdasarkan tahap kesejahteraan penduduknya. Oleh karena itu kajian kesejahteraan menarik mengingat ada sebagian masyarakat tidak menikmati hasil-hasil pembangunan secara maksimum. Diantara cara untuk 
melihat hasil pembangunan adalah dengan melihat kesejahteraan yang dirasakan masyarakat. Kesejahteraan ini tidak hanya meliputi aspek fisik tetapi juga aspek bukan fisik.

$\mathrm{Di}$ Indonesia, kesejahteraan manusia mulai mendapat perhatian ketika memulai rencana tahap pembangunan keempat yang dikenal dengan Rencana Pembangunan Lima Tahun (REPELITA). Konsep pembangunan berasaskan GBHN (Garis-Garis Besar Haluan Negara) yaitu bertujuan mencapai masyarakat Indonesia seutuhnya. Seutuhnya di sini mempunyai makna bahwa pembangunan tidak sekedar memenuhi keperluan fisik tetapi juga keperluan bukan fisik. Diantara pertanyaan yang muncul pada masa berkenaan adalah mengenai sejauh mana kesejahteraan penduduk yang dihasilkan daripada pembangunan (Dahlan, 1992).

Penelitian ini menggunakan perspektif disiplin ilmu geografi. Menurut Bintarto (1975) kajian geografi menumpukan pada hubungan kausal muka bumi yang terdiri daripada unsur fisik mahupun bukan fisik serta permasalahannya. Martopo (1995) juga menyatakan bahwa geografi merupakan ilmu pengetahuan yang mempelajari geosfer serta komponen-komponen secara terpadu, holistik dan sistematik dalam konteks keruangan, lingkungan dan kompleks wilayah demi kepentingan negara, perdamaian manusia dan ilmu pengetahuan.

Penelitian ini akan dilakukan di Banjarnegara. Banjarnegara merupakan salah satu kabupaten yang mempunyai keadaan lingkungan dan keadaan sosial ekonomi penduduk yang beragam. Diantara kenampakan geosfer yaitu kualitas penduduk di Banjarnegara yang mempunyai aneka kewujudan fisik dan sosio-ekonomi. Kesejahteraan penduduk tersebut merupakan hasil interaksi antara keadaan penduduk pada satu pihak dan keadaan lingkungan pada pihak lain. Kesejahteraan penduduk yang tinggi pada suatu kawasan, wujud melalui sinergi antara faktor internal penduduk dan faktor eksternal yang yang berasal dari lingkungan dalam struktur keruangan Banjarnegara.

Penelitian ini akan menggunakan analisis ruang waktu, maknanya dalam menganalisis kesejahteraan penduduk di Banjarnegara dikaji menurut perbedaan waktu dan ruang. Analisis yang akan dilakukan menumpukan pada keadaan kesejahteraan penduduk Banjarnegara antar kawasan. Masing-masing kawasan ini selain diambil karena faktor fisik dan jarak, juga diambil berdasarkan pertimbangan keadaan sosioekonomi penduduk. Perbedaan kesejahteraan antara masing-masing kelompok dikaji dalam penelitian ini.

Apakah pembangunan pada setiap negara telah mencapai sasaran? Pertanyaan ini dapat dijawab dengan cara menetapkan indikator keberhasilan pembangunan. Namun demikian, perlu dipastikan dahulu makna daripada pembangunan. Oleh karena itu indikator yang akan digunakan memang menunjukkan keberhasilan pembangunan tersebut. Konsep pembangunan menurut Bank Dunia dalam World Development Report, pembangunan mempunyai dua makna yaitu guna mempercepat pertumbuhan ekonomi dan mengurangkan kemiskinan (World Bank, 1978).

Dalam laporan tersebut, dinyatakan bahwa Gross National Product (GNP) merupakan indikator utama untuk mengukur keberhasilan pembangunan. Negaranegara di dunia ini diletakkan dalam satu rentang nilai menurut GNP dari negara yang paling miskin (low income countries) sehingga yang paling kaya (industrialized countries). PBB telah mengeluarkan seri laporan mengenai Indeks Pembangunan Manusia. Indeks ini disusun berdasarkan tiga indikator yaitu income, literacy rate dan life expectancy.

Perubahan penumpuan indikator pembangunan kepada indeks pembangunan manusia dipengaruhi oleh pergeseran mengenai konsep pembangunan itu sendiri. Meskipun secara konsisten Bank Dunia menggunakan GNP sebagai indikator utama, namun perlu disadari bahwa GNP tidak dapat secara penuh menggambarkan perubahan kehidupan suatu negara yang majemuk. Misalnya mengenai indikator angka harapan hidup, negara Cina, India dan Sri Lanka terpaksa dikecualikan karena walaupun termasuk dalam low-income-economy namun mempunyai angka harapan hidup yang tinggi. Pembangunan bukanlah semata-mata percepatan pertumbuhan ekonomi dan pembasmian kemiskinan tetapi memperluaskan pilihan-pilihan serta menjadikannya lebih demokratik dan parsipartoris. Demikian juga konsep pembangunan manusia menurut UNDP yaitu untuk memperluaskan pilihan misalnya untuk hidup sehat, hidup lebih lama, terdidik dan mandiri. Selain itu juga mempunyai akses terhadap fasilitas-fasilitas fisik dan sosial untuk memenuhi keperluan hidup.

Upaya pengembangan indikator pembangunan di Indonesia mempunyai sejarah yang panjang. Misalnya Biro Pusat Statistik menerbitkan "Indeks Kesejahteraan Rakyat" memanfaatkan variabel-variabel kependudukan, pendidikan kesehatan, gizi, konsumsi rumah tangga, angkatan kerja serta perumahan dan lingkungan sebagai indikator pembangunan. Indeks kesejahteraan rakyat yang dikeluarkan oleh Biro Pusat Statistik ini mempunyai kelebihan yaitu boleh dibandingkan antara provinsi di seluruh Indonesia karena data yang sedia ada. Namun demikian, indikator kesejahteraan rakyat ini mempunyai 
kelemahan yaitu kesemua indikator berkenaan tidak boleh dilihat secara terpadu.

Indikator kesejahteraan rakyat ini juga mencakup Indeks Mutu Hidup (IMH) atau Physical Quality of Life (PQLI) yang dikembangkan pada dekad tujuhpuluhan. Penambahan Total fertility Rate ke dalam IMH yang dilakukan oleh Sayogyo dan Abustam ternyata dapat digunakan sebagai petunjuk bahwa penurunan fertilitas di suatu provinsi berkaitan dengan peningkatan mutu hidup. IMH mempunyai tiga komponen. Ketiga-tiga komponen tersebut yaitu kemampuan baca tulis (literacy rate), harapai hidup selepas umur satu tahun (life expectancy) dan angka kematian bayi (infant mortality). IMH merupakan indikator komposit. Semakin kecil angka IMR, semakin baik keadaan kesejahteraan pada satu kawasan. Berdasarkan konsep ini dapat dijumpai negara yang mempunyai pendapatan perkapita tinggi tetapi ternyata IMH-nya rendah dan sebaliknya. Arab Saudi yang mempunyai pendapatan per kapita tinggi ternyata IMH-nya rendah, sebaliknya Sri Lanka yang pendapatan per kapita rendah mempunyai IMH yang baik.

Selain ketiga komponen tersebut pernah juga dicoba untuk menambahkan satu komponen lagi yaitu Total Fertility Rate (TFR) ke dalam komponen indeks mutu hidup. Nama Indeks Mutu Hidup yang baru ini adalah IMH-plus atau IMH berkomponen empat. Penambahan komponen TFR ini menghasilkan perbedaan yang cukup berarti. Provinsi yang mempunyai TFR terendah selalunya mempunyai IMHplus sama atau lebih tinggi dari IMH. Jadi, semakin rendah tingkat fertilitas semakin besar IMH-plus jika dibandingkan dengan IMH.

Selain indikator komposit obyektif, indikator komposit subyektif juga disusun oleh Biro Pusat Statistik. Indikator ini secara umumnya berisi maklumat mengenai persepsi masyarakat mengenai tingkat kesejahteraan rumah tangga selama tiga tahun kebelakangan. Indikator ini meliputi: (1) kemudahan menyekolahkan anak di Sekolah Dasar; (2) kemudahan menyekolahkan anak di Sekolah Menengah Tingkat Pertama; (3) keadaan perayaan hari lebaran; (4) kemudahan menggunakan fasilitas pengangkutan; (5) ketertiban/keamanan; (6) kesehatan anggota rumah tangga; (7) fasilitas tempat tinggal; (8) keadaan ekonomi rumah tangga; (9) perbandingan pendapatan dan konsumsi.

Kajian mikro mengenai kesejahteraan telah dilakukan antaranya oleh Pacione (2003). Pacione mengkaji kesejahteraan penduduk kawasan Kota Glasgow, Scodland. Kajian ini menggunakan perspektif geografi. Kesejahteraan penduduk dalam kajian ini dikaitkan dengan keadaan lingkungan serta penyesuaian diri penduduk terhadap lingkungan sama ada lingkungan fisik mahupun lingkungan sosial. Sedangkan Seik (2000) mengkaji secara subjektif daripada sisi penduduk kota di Singapura. Kajian ini melingkupi aspek kehidupan berkeluarga, pendidikan, pariwisata, media, pengembangan diri, kehidupan sosial, kehidupan pekerjaa, kekayaan, kesehatan, pembelajaan.

Izutsu et al. (2006) mengkaji kesejahteraan menurut WHO Quality of Life assessment instrument yaitu melingkupi aspek fisik, psikologi, relasi sosial dan lingkungan. Aspek ini perlu ditambah untuk mengetahui keadaan kesejahteraan secara lebih lengkap misalnya aspek ekonomi. Kajian ini lebih ditumpukan pada aspek psikologi dan kesehatan karena selain kesejahteraan, aspek kesehatan mental dan gizi mendapat perhatian yang mendalam. Dalam kajian ini kawasan slum dibandingkan dengan kawasan tidak slum di Bangladesh. Sedangkan penelitian di Indonesia secara mendalam mengenai berbagai aspek kehidupan rumah tangga yang juga menggambarkan keadaan kehidupan keluarga pada masyarakat pada tahun 2000. Survei ini dinamai Survei Kehidupan Rumah Tangga Indonesia 2000 (SAKERTI). Penelitian ini meliputi aspek-aspek lingkungan rumah, kesehatan, keadaan rumah dan fasilitasnya, pekerjaan, gangguan ekonomi, pendidikan, bantuan, partisipasi sosial, riwayat perkawinan, morbiditas.

Penelitian lainnya juga dilakukan secara mendalam dalam skala nasional dilakukan oleh Badan Pusat Statistik setiap tahun yang memberikan data pokok mengenai kesejahteraan penduduk. Penelitian ini dilakukan setiap tahun sehingga dapat membelikan maklumat secara berkala. Penduduk yang diselidik adalah sebagian penduduk Indonesia (249.376 rumah tangga untuk survey tahun 2005). Survei ini disebut Survei Sosial Ekonomi Nasional atau SUSENAS). Aspek-aspek yang dikaji melingkupi ciri-ciri demografi, pendidikan, kesehatan, ketenagakerjaan, fertilitas dan keluarga berencana.

Berdasarkan indicator-indikator mengenai kesejahteraan yang telah digunakan oleh peneliti sebelumnya, negara maupun $\mathrm{PBB}$ serta mempertimbangkan keadaan Banjarnegara maka penelitian ini akan menggunakan indikator kesejahteraan sebagai berikut. (1) Kualitas lingkungan fisik yaitu keadaan rumah, pengaturan lingkungan, kebersihan, kenyamanan dan keselamatan lingkungan, sarana dan prasarana. (2) Kualitas lingkungan sosial yaitu kesehatan, pendidikan, penyertaan dalam masyarakat, peribadatan, keselamatan, perkawinan dan perceraian, hiburan. (3) Kualitas lingkungan ekonomi yaitu pekerjaan, penghasilan, konsumsi, kekayaan, 
gangguan ekonomi, bantuan. (4) Kualitas lingkungan media, pengangkutan, komunikasi yaitu pencapaian fasilitas pengangkutan, pencapaian fasilitas media, pencapaian fasilitas komunikasi.

Kajian mengenai kesejahteraan telah dilakukan sejak 1930-an (Wish, 1986). Beberapa pakar menggunakan indikator yang beraneka serta membandingkannya dalam ruang geografi seperti kota atau desa maupun membandingkan antar etnik (Burc et al., 2011; Blomquist et al., 2012; Mohhamed dan Carolyn, 2002; Julian, 2003; ذirojanakul et al., 2003; Vernon, 2012). Pacione (2003) menggunakan perspektif geografi dalam kajiannya mengenai kualitas lingkungan kota dan kesejahteraan manusia. Dalam kajiannya Pacione menemukan adanya pengaruh keadaan lingkungan kepada kehidupan masyarakat yang berada di kawasan tersebut. Berbagai masalah sosial wujud dalam masyarakat di kota Gasglow antara lain masalah ketenagakerjaan, pendidikan bagi masyarakat miskin, perumahan yang buruk, kriminalitas, kurangnya fasilitas pariwisata, kurangnya tempat bermain, tidak mesranya masyarakat umum, interaksi yang buruk dengan polisi. Pacione (2003) juga menyatakan bahwa indikator sosial kesejahteraan dapat dibagikan dalam dua bagian. Pertama, dilihat dari aspek objektif yaitu aspek lingkungan penduduk (hidup dan kerja), taraf pelayanan kesehatan, pendidikan, fasilitas pariwisata, perumahan. Kedua, indikator subjektif yaitu cara penduduk menerima dan menilai keadaan lingkungan. Tujuan penelitian yaitu (a) mengkaji dinamika kesejahteraan penduduk Banjarnegara; dan (b) mengkaji perbedaan kesejahteraan menurut wilayah di Banjarnegara.

\section{METODE PENELITIAN}

Banjarnegara diambil sebagai tempat kajian karena pertimbangan sebagai berikut. Banjarnegara merupakan suatu wilayah administrasi yang di dalamnya wujud kawasan yang mempunyai keadaan sosio-ekonomi dan lingkungan fisik yang beragam dan merupakan salah daerah yang berperan secara sosial, politik dan ekonomi. Daerah ini dikenal sejak lama telah memperlihatkan indikator-indikator kependudukan yang relatif baik. Apabila demikian, apakah kebaikan indikator-indikator itu juga telah mempunyai tingkat ketersampaian hasil-hasil pembangunan terhadap penduduknya ataukah belum. Hal ini dapat dilihat dari kesejahteraan dan analisis kesejahteraan dari persepsi penduduk juga amat diperlukan untuk perencanaan maupun evaluasi pembangunan di Banjarnegara.

Data yang dikumpulkan untuk mencapai tujuan penelitian adalah data dari BPS Banjarnegara dan BPS provinsi Jawa tengah menyangkut data setiap aspek kesejahteraan penduduk serta aspek-aspek pendukung. Data juga kantor Departemen Tenaga Kerja Banjarnegara, Dinas Permukiman dan Prasarana Wilayah, Badan Perencana dan Pembangunan Daerah. Data yang dimaksudkan yaitu data deskripsi kawasan, data perumahan, data standar hidup, program pembangunan pendudukan pada Banjarnegara.

Data yang telah dihimpun dianalisis secara kuantitatif berdasarkan penskoran variabel tiap-tiap aspek. Aspek yang digunakan mempertimbangkan variabel yang dipilih oleh Coates et al. (1977) dan Miller et al. (1967) dan Smith (1973), UN (UNRISD) (1966), Asmah Ahmad (1999), Azahan (2006), Badan Pusat Statistik Jakarta (2006, 2014) untuk menggambarkan kesejahteraan penduduk. Indikator Kesejahteraan tersebut meliputi perumahan, kesehatan, pendidikan, kestabilan sosial, lingkungan sekitar dan ekonomi.

\section{HASIL DAN PEMBAHASAN}

\section{Variasi Keruangan Kesejahteraan Penduduk di Kabupaten Banjarnegara}

Kabupaten Banjarnegara merupakan salah satu Kabupaten yang ada di Provinsi Jawa Tengah. Wilayah Kabupaten Banjarnegara memiliki luas $1.070 \mathrm{~km}^{2}$. Kabupaten Banjarnegara terbagi dalam 20 kecamatan yang terdiri dari 266 desa dan 12 kelurahan. Kabupaten Banjarnegara terletak pada daerah yang mempunyai topografi perbukitan hingga pegunungan, yaitu Pegunungan Serayu Utara dan Pegunungan Serayu Selatan yang membujur barat - timur dan dipisahkan oleh Sungai Serayu yang membentuk lembah serta kondisi geologi yang kompleks (Kinasti, 2014).

Dalam ilmu Geografi, variasi keruangan dalam berbagai aspek penduduk menjadi salah satu aspek penting. Variasi keruangan ini merupakan bentuk cerminan perbedaan sosial, budaya, maupun pembangunan dan segala prosesnya. Perhatian terhadap variasi keruangan inilah yang dikemukakan oleh Harvey (1972) dan Smith (1974) sebagai unsur mendasar dalam Geografi.

Berbagai usaha untuk mengukur kesejahteraan telah lama diusahakan oleh para pakar. Perbedaan dalam mengukur kesejahteraan tersebut terjadi menurut nilai, sudut pandang kajian, penekanan dan tujuan. Namun dibalik keberagaman dalam pengukuran kesejahteraan tersebut, ada konsesus bahwa secara garis besar disepakati bahwa kesejahteraan bermakna pula menurunnya kemiskinan dan meningkatnya keadilan sosial. Kesejahteraan merupakan proses multidimensi yang melibatkan 
kesejahteraan pada aspek kuantitas dan kualitas dalam kehidupan (Asmah, 1999).

Beberapa kajian telah dilakukan dalam upaya memperoleh consensus umum untuk mengetahui apa itu kesejahteraan (Wish, 1986; Veenhoven, 2000; Sufian, 1993; Smith,1977; Cummins, 2000; Blomquist et al., 1988; Smith, et al., 1997). Hal ini dilakukan untuk memperoleh kesepakatan bersama mengenai apa itu kesejahteraan. Secara umum ada kesepakatan bahwa suatu kesejahteraan itu memposisikan secara penting komponen-komponen tingkat ekonomi, pakaian, rekreasi, perumahan (perumahan), kesehatan, dan kemandirian, pendidikan, kestabilan sosial dan keamanan.

Kesejahteraan penduduk di wilayah Kabupaten Banjarnegara berdasarkan indikator terukur menunjukkan bahwa tidak selalu yang mempunyai ciri kekotaan menempati posisi tertinggi. Contohnya adalah Kecamatan Banjarnegara yang merupakan ibukota Kabupaten lebih rendah posisinya dibandingkan Kecamatan Klampok. Kecamatan Klampok memang mengalami kemajuan yang pesat terkait aktivitas ekonominya sehingga terlihat sektor jasa dan perdagangan maju. Namun demikian variabel kesejahteraan lainnya masih lebih bagus keadaannya dibandingkan Banjarnegara. Misalnya adalah terkait dengan keadaan lingkungan di mana pencemaran udara lebih besar di kecamatan Banjarnegara daripada di Klampok (Tabel 1).

Kecamatan yang posisinya jauh dari ibukota kecamatan seperi Pandanarum, Kalibening, wanayasa, Batur terlihat perubahan kesejahteraannya teruma dari tahun 2003 ke tahun 2013 menduduki posisi yang lebih rendah dibanding kecamatan lainnya. Hal ini dipengaruhi keadaan sumberdaya di kecamatan ini serta faktor lain termasuk jarak dari pusat kabupaten. Jarak kecamatan terhadap pusat kabupaten dianggap mempunyai kaitan dengan keadaan kesejahteraan penduduk mengingat banyak fasilitas dan aktivitas sosial, ekonomi yang relatif baik berada di pusat kabupaten. Jarak yang jauh mengurangi akses terhadap fasilitas tersebut. Berkurangnya akses menyebabkan keadaan aspek terkait kurang baik pula.

Kecamatan yang didominasi pertanian namun telah berkembang pula sektor perdagangan dan jasa menduduki peringkat terbaik dalam hal kesejahteraan. Selain Klampok, diketahui bahwa Kecamatan Kecamatan Bawang, Kecamatan Purwanegara, Kecamatan Banjarmangu, Kecamatan Punggelan, Kecamatan Rakit, Kecamatan Mandiraja, Kecamatan Kalibening, Kecamatan Madukara, Kecamatan Pagedongan dan Karangkobar. Kesejahteraan kurang baik dibandingkan kecamatan yang lain adalah di
Pandanarum, Pagentan, Pajawaran, Rakit, Kalibening. Kecamatan ini didominasi aktivitas pertanian dengan beberapa aspek terlihat relatif lebih rendah keadaannya dibandingkan daerah lain misalnya keadaan perumahan, pendidikan.

Tabel 1. Peringkat Perubahan Kesejahteraan Penduduk di Banjarnegara 20 Tahun Terakhir

\begin{tabular}{clcc}
\hline No & Kecamatan & $1993-2003$ & $2003-2013$ \\
\hline 1 & Susukan & 11 & 9 \\
2 & Purwareja Klampok & 2 & 3 \\
3 & Mandiraja & 8 & 2 \\
4 & Purwanegara & 4 & 15 \\
5 & Bawang & 3 & 14 \\
6 & Banjarnegara & 1 & 8 \\
7 & Pagedongan & 17 & 7 \\
8 & Sigaluh & 13 & 10 \\
9 & Madukara & 10 & 5 \\
10 & Banjarmangu & 5 & 6 \\
11 & Wanadadi & 12 & 1 \\
12 & Rakit & 7 & 18 \\
13 & Punggelan & 6 & 19 \\
14 & Karangkobar & 18 & 4 \\
15 & Pagentan & 14 & 11 \\
16 & Pejawaran & 19 & 12 \\
17 & Batur & 15 & 13 \\
18 & Wanayasa & 16 & 20 \\
19 & Kalibening & 9 & 17 \\
20 & Pandanarum & 20 & 16 \\
\hline$\times$ Keterangan:angka & & $29 n$
\end{tabular}

${ }^{\star}$ Keterangan: angka yang kecil menunjukkan peringkat yang lebih bagus

\section{Dinamika Kesejahteraan Penduduk Banjarnegara 2003-2013}

Kesejahteraan penduduk di Banjarnegara mengalami dinamika. Secara umum, pola yang terlihat penduduk menjadi semakin sejahtera. Namun demikian, terlihat perbedaan perubahan kesejahteraan antar kecamatan. Daerah yang sejak awal telah maju terlihat perubahan lebih rendah jika dibandingkan dengan daerah yang sebelumnya belum terlalu sejahtera dibandingkan daerah yang maju tersebut. Misalnya Kecamatan Banjarnegara yang perubahan kesejahteraannya tidak sebesar daerah di sekitarnya misalnya Klampok, Purwareja, Madukara, karangkobar (Tabel 2). Kecamatan-kecamatan ini tidak jauh letaknya dari ibukota kecamatan sehingga penduduk dapat mengakses fasilitas di pusat kabupaten dengan mudah dan berbagai aktivitas menjadi lancar. 
Tabel 2. Peringkat Kesejahteraan Penduduk Antar Kecamatan di Kabupaten Banjarnegara Tahun 2013

\begin{tabular}{|c|c|c|c|c|c|c|c|c|}
\hline No & Kecamatan & Pendidikan & kesehatan & Perumahan & Kestabilan Sosial & Lingkungan & Ekonomi & Total \\
\hline 1 & Susukan & 12 & 15 & 17 & 15 & 8 & 13 & 12 \\
\hline 2 & Purwareja Klampok & 9 & 5 & 6 & 13 & 15 & 6 & 3 \\
\hline 3 & Mandiraja & 7 & 9 & 5 & 4 & 14 & 7 & 5 \\
\hline 4 & Purwanegara & 17 & 13 & 11 & 19 & 17 & 4 & 17 \\
\hline 5 & Bawang & 16 & 2 & 3 & 16 & 16 & 5 & 16 \\
\hline 6 & Banjarnegara & 2 & 6 & 2 & 10 & 20 & 1 & 2 \\
\hline 7 & Pagedongan & 8 & 18 & 18 & 1 & 7 & 12 & 8 \\
\hline 8 & Sigaluh & 11 & 10 & 19 & 18 & 18 & 3 & 11 \\
\hline 9 & Madukara & 3 & 3 & 20 & 17 & 19 & 2 & 9 \\
\hline 10 & Banjarmangu & 5 & 16 & 7 & 20 & 12 & 9 & 7 \\
\hline 11 & Wanadadi & 6 & 1 & 9 & 3 & 13 & 8 & 6 \\
\hline 12 & Rakit & 18 & 12 & 14 & 14 & 11 & 10 & 18 \\
\hline 13 & Punggelan & 1 & 4 & 13 & 2 & 10 & 11 & 1 \\
\hline 14 & Karangkobar & 4 & 8 & 10 & 5 & 9 & 14 & 4 \\
\hline 15 & Pagentan & 14 & 7 & 12 & 8 & 6 & 15 & 14 \\
\hline 16 & Pejawaran & 15 & 14 & 16 & 11 & 2 & 19 & 15 \\
\hline 17 & Batur & 10 & 20 & 4 & 12 & 5 & 16 & 10 \\
\hline 18 & Wanayasa & 13 & 11 & 15 & 9 & 4 & 17 & 13 \\
\hline 19 & Kalibening & 19 & 19 & 1 & 6 & 5 & 18 & 19 \\
\hline 20 & Pandanarum & 20 & 17 & 8 & 7 & 1 & 20 & 20 \\
\hline
\end{tabular}

Sumber: Olahan Data Kabupaten dalam Angka

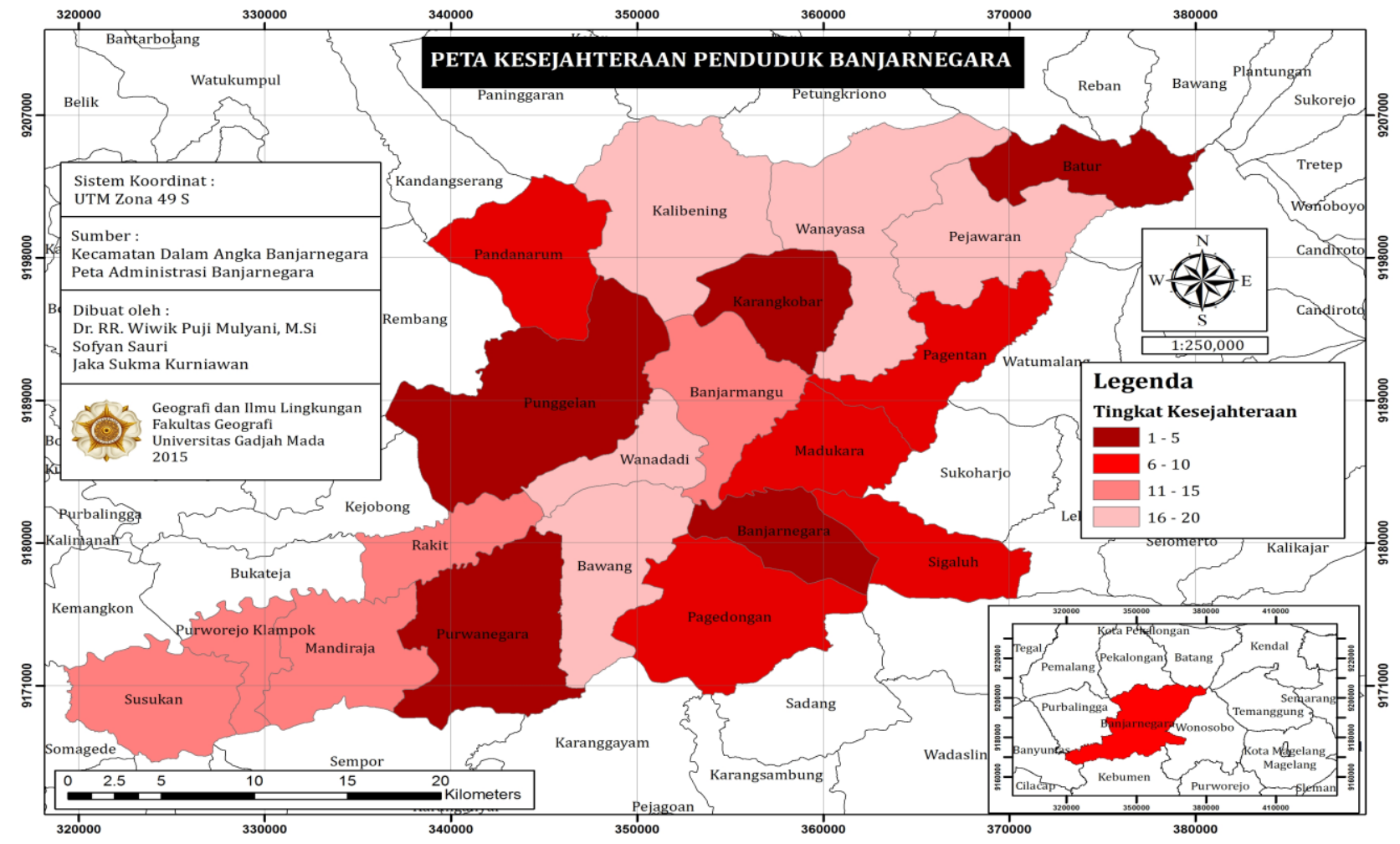

Gambar 1. Peta Perubahan Kesejahteraan Penduduk di Banjarnegara 2003-2013 


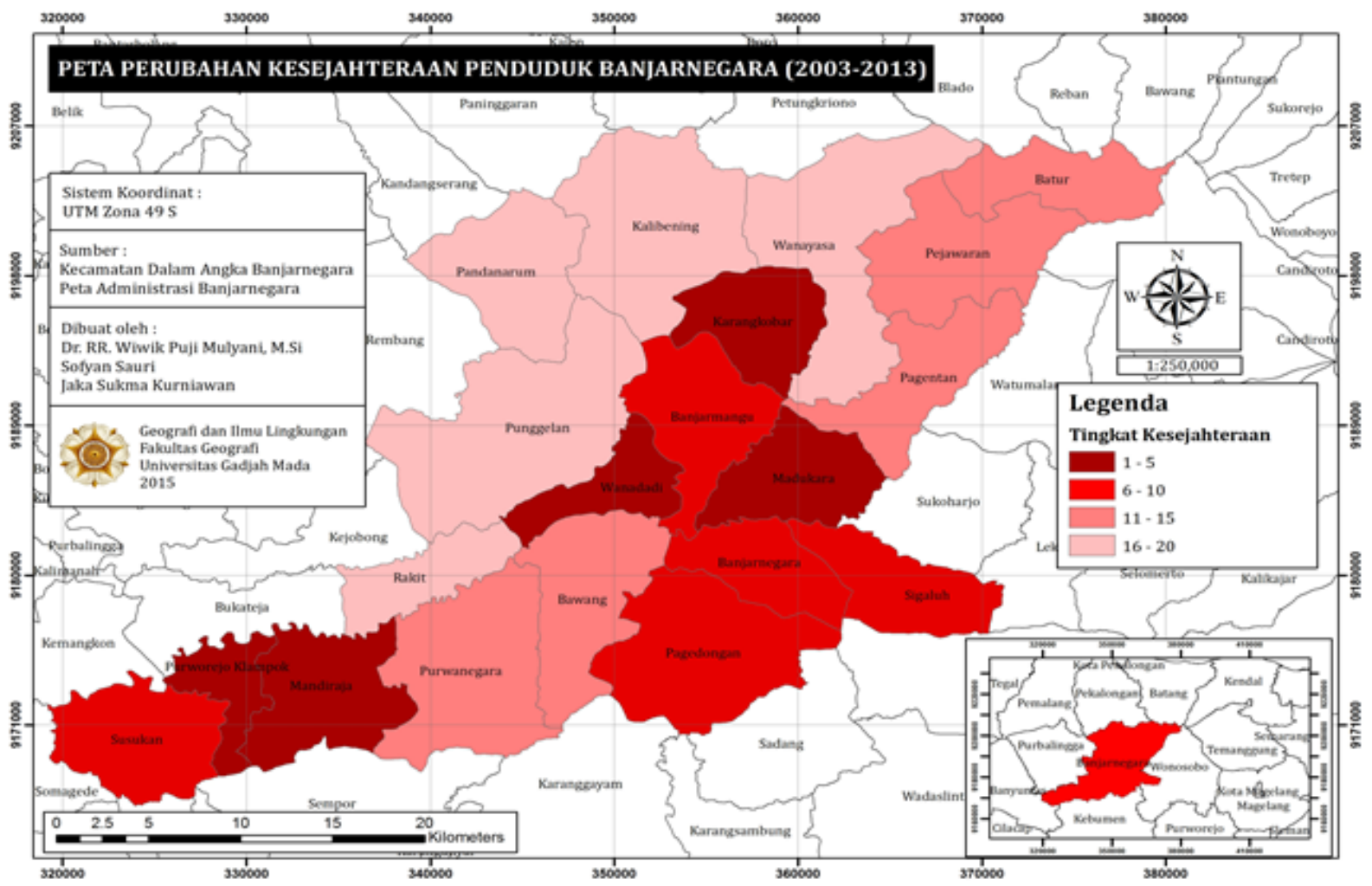

Gambar 2. Peta Perubahan Kesejahteraan Penduduk di Banjarnegara 2003-2013

\section{KESIMPULAN}

Secara umum, Kesejahteraan penduduk di wilayah Kabupaten Banjarnegara berdasarkan indikator terukur menunjukkan bahwa tidak selalu yang mempunyai ciri kekotaan selalu menempati posisi tertinggi. Contohnya adalah Kecamatan Banjarnegara yang merupakan ibukota Kabupaten lebih rendah posisinya dibandingkan Kecamatan Klampok. Kecamatan Klampok memang mengalami kemajuan yang pesat terkait aktivitas ekonominya sehingga terlihat sektor jasa dan perdagangan maju. Namun demikian variabel kesejahteraan lainnya masih lebih bagus keadaannya dibandingkan Banjarnegara. Misalnya adalah terkait dengan keadaan lingkungan di mana pencemaran udara lebih besar di kecamatan Banjarnegara daripada di Klampok.

Kecamatan yang merupakan "transisi" yang maksudnya adalah daerah yang didominasi pertanian namun telah berkembang pula sektor perdagangan dan jasa menduduki peringkat terbaik dalam hal kesejahteraan. Selain Klampok, diketahui bahwa Kecamatan Kecamatan Bawang, Kecamatan Purwanegara, Kecamatan Banjarmangu, Kecamatan Punggelan, Kecamatan Rakit, Kecamatan Mandiraja, Kecamatan Kalibening, Kecamatan Madukara, Kecamatan Pagedongan dan Karangkobar.
Kesejahteraan kurang baik dibandingkan kecamatan yang lain adalah di Pandanarum, Pagentan, Pajawaran, Rakit, Kalibening. Kecamatan ini didominasi aktivitas pertanian dengan beberapa aspek terlihat relatif lebih rendah keadaannya dibandingkan daerah lain. Misalnya keadaan perumahan, pendidikan selain faktor ekonomi.

\section{DAFTAR PUSTAKA}

Abdul M.B., Zurinah S., Hamidi Ismail. (2002). Indeks kesejahteraan dan Sistem Maklumat Geografi (GIS): satu Penelitian dalam Lukman, Z. M. (eds). Impak pembangunan. Kesejahteraan dan lingkungan. Kuala Lumpur: AG Grafis.

Badan Pusat Statistik. (2014). Kabupaten Banjarnegara Dalam Angka tahun 2013. Banjarnegara: Badan Pusat Statistik.

Bintarto. (1975). Pengantar Geografi Pembangunan. Yogyakarta: UP Spring.

Blomquist, G.C., Berger, M.C., Hoehn, J.P. (2012). New estimates of quality of life in urban areas. American Economic Review. 78 (1), 89-107.

Burc Ulengin, Fusun Ulengin, Umit Guvencfl. (2012). A multidimensional approach to urban quality of life: The Case of Istanbul. Economic Review. 78 (1), 89-107

http://jurnal.ugm.ac.id/mgi | 102 
Frank, G.A. (1978). Development Accumulation and Underdevelopment. London: Mcmillan.

Izutsu, Takhasi, Atsuro Thutsumi, Akramul Md. Islam, Seiko Kato, Susumu Wakai \& Hiroshi Kurita. (2006). Mental health, Quality of life, and nutrition status of adolescent in Dhaka, Bangladesh: Comparation between and Urban Slum and nonslum area. Social Science and Medicine. 63: 14771488 .

Jironakul, Pragai., Suzanne M.S., John H. Predicting young children's quality of life. Social Science and Medicine. 57: 1277-1288.

Julian Thumboo, KY Fong, David M, SP Chan, CH Soh, KH Leong, PH Peng, ST Thio, ML Boey. (2003). Quality of Life in An Urban Asian Population: The Impact of Ethnicity and SocioEconomic Status. Social Science and Medicine. 56: 1761-1772.

Kinasti, M. A. (2014). Pengaruh Struktur Geologi Terhadap Gerakan Tanah Di Dusun Windusari, Desa Metawana, Kecamatan Pagentan Kabupaten Banjarnegara, Provinsi Jawa Tengah. Jurnal Ilmiah MTG. 7(1).

Lukman Z.M., Abdul A.J., Mohd Y.H., Faridatul A.S. (2002.) Dilema pembangunan. Satu sorotan dalam Lukman, Z. M. (eds). Impak pembangunan. Kesejahteraan dan Lingkungan. Kuala Lumpur: AG Grafis. Hal 38-61.
Martopo, Sugeng. (1995). Asas Keseimbangan Lingkungan Dalam Geografi dan Penerapannya dalam Pembangunan. Pidato dies ke-3 Fakultas Geografi, Universitas Gadjah Mada.

Mohammad Hemmasi and Carolyn V. Prorok. (2012). Women's migration and quality of life in Turkey. Geoforum. 33: 399-411.

Munck, R. (2013). Democracy and development: deconstruction and debates dalam Sklair, L. (ed). Capitalism and Development. London: Rouledge. Hal 89-121.

Pacione, M. (2003). The quality of the urban lifespace-a geographical perspective. Dalam: Bonnes, M. (Ed.), Perception and Evaluation of Urban Environmental Quality. UNESCO, Rome, pp. 17-42.

Seik, Foo Tuan. (2011). Subjective Assessment of Urban Quality of Life in Singapore (1997/1998). Habitat International. 34: 31-49.

Todaro, M.P. (1991). Economic Development in Third World. New York: Longman.

Vernon Henderson. (2012). Urban primacy, external costs, and quality of life. Resources and Energy Economics 24: 95-106.

World Bank. (1978). World Development. Report. Washington, D.C.: The World Bank. 
